\title{
UCP3 protein expression is lower in type I, Ila and IIx muscle fiber types of endurance-trained compared to untrained subjects
}

Citation for published version (APA):

Russell, P., Wadley, G., Hesselink, M. K. C., Schaart, G., Lo, S., Leger, B., Garnham, A., Kornips, C. F. P., Cameron-Smith, D., Giacobino, J. P., Muzzin, P., Snow, R., \& Schrauwen, P. (2003). UCP3 protein expression is lower in type I, Ila and IIx muscle fiber types of endurance-trained compared to untrained subjects. Pflugers Archiv-European Journal of Physiology, 445(5), 563-569.

https://doi.org/10.1007/s00424-002-0943-5

Document status and date:

Published: 01/01/2003

DOI:

10.1007/s00424-002-0943-5

Document Version:

Publisher's PDF, also known as Version of record

Document license:

Taverne

Please check the document version of this publication:

- A submitted manuscript is the version of the article upon submission and before peer-review. There can be important differences between the submitted version and the official published version of record.

People interested in the research are advised to contact the author for the final version of the publication, or visit the DOI to the publisher's website.

- The final author version and the galley proof are versions of the publication after peer review.

- The final published version features the final layout of the paper including the volume, issue and page numbers.

Link to publication

\footnotetext{
General rights rights.

- You may freely distribute the URL identifying the publication in the public portal. please follow below link for the End User Agreement:

www.umlib.nl/taverne-license

Take down policy

If you believe that this document breaches copyright please contact us at:

repository@maastrichtuniversity.nl

providing details and we will investigate your claim.
}

Copyright and moral rights for the publications made accessible in the public portal are retained by the authors and/or other copyright owners and it is a condition of accessing publications that users recognise and abide by the legal requirements associated with these

- Users may download and print one copy of any publication from the public portal for the purpose of private study or research.

- You may not further distribute the material or use it for any profit-making activity or commercial gain

If the publication is distributed under the terms of Article $25 \mathrm{fa}$ of the Dutch Copyright Act, indicated by the "Taverne" license above, 
A. P. Russell • G. Wadley • M. K. C. Hesselink •

G. Schaart - S. Lo · B. Léger - A. Garnham •

E. Kornips $\cdot$ D. Cameron-Smith · J.-P. Giacobino •

P. Muzzin $\cdot$ R. Snow $\cdot$ P. Schrauwen

\section{UCP3 protein expression is lower in type I, Ila and IIx muscle fiber types of endurance-trained compared to untrained subjects}

Received: 19 April 2002 / Revised: 5 August 2002 / Accepted: 27 August 2002 / Published online: 23 November 2002

(C) Springer-Verlag 2002

\begin{abstract}
Uncoupling protein 3 (UCP3) is a muscle mitochondrial protein believed to uncouple the respiratory chain, producing heat and reducing aerobic ATP production. Our aim was to quantify and compare the UCP3 protein levels in type I, IIa and IIx skeletal muscle fibers of endurance-trained (Tr) and healthy untrained (UTr) individuals. UCP3 protein content was quantified using Western blot and immunofluorescence. Skeletal muscle fiber type was determined by both an enzymatic ATPase stain and immunofluorescence. UCP3 protein expression measured in skeletal muscle biopsies was $46 \%$ lower $(P=0.01)$ in the $\operatorname{Tr}$ compared to the UTr group. UCP3 protein expression in the different muscle fibers was expressed as follows; IIx $>$ IIa $>$ I in the fibers for both groups $(P<0.0167)$ but was lower in all fiber types of the Tr when compared to the UTr subjects $(P<0.001)$. Our results show that training status did not change the skeletal muscle fiber hierarchical UCP3 protein expression in the different fiber types. However, it affected UCP3 content more in type I and type IIa than in the type IIx muscle fibers. We suggest that this decrease may be in relation to the relative improvement in the antioxidant defense systems of the skeletal muscle fibers and that it
\end{abstract}

A.P. Russell $(\bullet) \cdot$ B. Léger · J.-P. Giacobino · P. Muzzin

Department of Medical Biochemistry, University of Geneva, CMU, Switzerland

e-mail: aaron.russell@crr-suva.ch

Tel.: +41-27-6032077

Fax: +41-27-6032042

G. Wadley · A. Garnham · D. Cameron-Smith · R. Snow

School of Health Sciences, Deakin University, Burwood, Australia

E. Kornips · P. Schrauwen

Department of Human Biology, Maastricht University,

The Netherlands

M.K.C. Hesselink · G. Schaart

Department of Movement Sciences, Maastricht University,

The Netherlands

S. Lo

Institute for International Health, University of Sydney, Australia might, as a consequence, participate in the training induced improvement in mechanical efficiency.

Keywords Exercise - Oxidative phosphorylation .

Skeletal muscle

\section{Introduction}

Uncoupling protein 3 (UCP3) belongs to the family of mitochondrial carrier proteins and is expressed predominantly and abundantly in rodent and human skeletal muscle [1]. UCP3 is thought to uncouple oxidative phosphorylation, reducing aerobic ATP production and dissipating energy as heat. If this is the case UCP3 may play an important role in the regulation of human energy expenditure [2, 3, 4, 5]. Alternatively, based on UCP3 mRNA data it was proposed that UCP3 may also be involved in the exit of fatty acids out of the mitochondrial matrix [6], insulin sensitivity [7], protection against both reactive oxygen species [8] and the accumulation of nonesterified fatty acids inside the mitochondrial matrix [9]. Recent protein data have suggested that UCP3 may also play a role in regulating glucose homeostasis [10].

Endurance training has been frequently used as a model of altered energy metabolism. It has been observed to increase resting metabolic rate [11] and gross energy efficiency during exercise in humans [12]. UCP3 mRNA is decreased in rat muscle after 8 weeks of forced treadmill running [13] and is also reduced in endurancetrained (Tr) humans when compared to untrained (UTr) controls $[14,15]$. These observations support a role for UCP3 as a regulator of energy efficiency.

The study of the expression of the UCP3 protein was delayed as compared to that of the mRNA due to the lack of specific UCP3 antibodies. Recent measurements of the UCP3 protein level using validated UCP3 antibodies have revealed differences between the magnitude of changes for the UCP3 mRNA and protein. Conditions such as starvation [16], fasting [17] and triiodothyronine (T3) treatment [18] caused changes of UCP3 expression which 
were found to be several-fold higher at the UCP3 mRNA than the protein level. It has also been shown that under certain conditions, such as leptin treatment, the effects on UCP3 mRNA and protein are divergent [17]. All these results suggest that UCP3 can be regulated at the posttranscriptional level [17] and therefore underscore the need for examining UCP3 protein content rather than mRNA levels.

In a recent review, results from a preliminary study demonstrated a reduced UCP3 protein expression after 3 months of endurance training in previously untrained subjects [9]. An initial aim of the present study was to determine if the UCP3 protein content is lower in a group of UTr when compared to Tr subjects

Recently, it has been demonstrated in healthy and type II diabetic humans that the UCP3 protein is expressed the least in oxidative type I, more in oxidative-glycolytic type IIa and the most in glycolytic type IIx (also known as IIb) muscle fibers [19]. Since endurance training improves oxidative capacity of all muscle fiber types [20] it was of great interest to test its possible effect on the hierarchy of UCP3 protein expression in the different muscle fiber types. The second aim of this study was to measure and compare the UCP3 protein expression in the different muscle fiber types of the UTr and Tr groups.

\section{Materials and methods}

Ten recreationally active, but untrained male subjects (UTr) and eight highly trained endurance male cyclists (Tr) participated in the present study. Subject details are provided in Table 1. All subjects signed informed consent and volunteered to participate in the present experiment that was approved by the Deakin University Ethics Committee. The subjects were asked not to participate in any physical activity $24 \mathrm{~h}$ prior to testing and to abstain from eating for at least $3 \mathrm{~h}$ prior to testing.

\section{Exercise tests}

Each subject performed an incremental exercise test on an electromagnetically braked cycle ergometer (Lode Excalibur) to determine maximal oxygen consumption $\left(\dot{V}_{2}\right.$ max $)$ and maximal power output (MPO). Exercise was performed until exhaustion or until the subject could no longer maintain a pedaling rate of $90 \mathrm{rpm}$. Oxygen consumption and carbon dioxide production were measured using open-circuit spirometry (Medical Graphics, $\mathrm{CardiO}_{2}$ and CPX/D System). $\dot{V} \mathrm{O}_{2} \max$ was defined either when a plateau in $\dot{V} \mathrm{O}_{2}$ with increasing work rates was observed or as the highest 30 -s $\dot{V} \mathrm{O}_{2}$ value measured during the test. A plateau was deemed to be reached when $\dot{V} \mathrm{O}_{2}$ did not increase by more than $100 \mathrm{ml} / 13-\mathrm{W}$ increase. MPO was deemed as the highest power output at a cadence of $90 \mathrm{rpm}$ that could be maintained for a period of $60 \mathrm{~s}$ during the $\dot{V} \mathrm{O}_{2}$ max test. On a separate day, using the same equipment as for the measurement of $\dot{V} \mathrm{O}_{2}$ max, the mechanical efficiency (\%) of seven $\operatorname{Tr}$ and seven UTr subjects was calculated as steady-state energy expenditure $\left(\dot{V} \mathrm{O}_{2}\right) /$ power output $(\mathrm{W})$ when cycling at $50 \%$ of $\dot{V O}_{2}$ max power.
Muscle sampling, treatment and analysis

Skeletal muscle samples were obtained under local anesthesia (xylocaine, 1\% plain) from the belly of the vastus lateralis muscle using a percutaneous needle biopsy technique [21] modified to include suction. A single incision was made in the skin and two muscle samples were taken from a single insertion of the biopsy needle. After the first biopsy cut the needle was rotated and a second cut was performed. Each muscle sample weighed between $50 \mathrm{mg}$ and $80 \mathrm{mg}$. One muscle sample was mounted in embedding medium and frozen in isopentane, that was previously cooled to its freezing point. These samples were used for Western blotting, muscle fiber typing and immunohistochemistry. From the other muscle sample approximately $10 \mathrm{mg}$ of muscle was homogenized in a solution consisting of $175 \mathrm{mM} \mathrm{KCl}$ and $2 \mathrm{mM}$ EDTA ( $\mathrm{pH} 7.4$ ) and then freeze-thawed twice. The homogenate was then centrifuged for $1 \mathrm{~min}$ at $10,000 \mathrm{rpm}$ and the supernatant analyzed for citrate synthase (CS) activity using spectrophotometric detection [22]. CS activity correlates highly with in vitro measurements of skeletal muscle mitochondrial oxidative capacity [23] and has been commonly used as a marker of muscle oxidative capacity [24, 25]

\section{Histochemical staining}

Serial cross sections $10 \mu \mathrm{m}$ thick were cut from the mounted muscle sample in a cryostat maintained at $-20^{\circ} \mathrm{C}$. The sections for fiber typing were preincubated at $\mathrm{pH} 4.30$ and 4.54 , and were classified as either type I, IIa or IIx according to the acid lability of different isoforms of myosin ATPase [26]. For each subject, a minimum of 200 fibers were classified and each fiber type was expressed as a percentage of the total number counted.

\section{Western blotting}

For each muscle sample, sections approximately $40 \mu \mathrm{m} \times 20 \mu \mathrm{m}$ were cut at $-20^{\circ} \mathrm{C}$. They were placed in $400 \mu \mathrm{l}$ of ice-cold PBS containing $0.4 \mathrm{mM}$ phenyl methyl sulfonyl fluoride (PMSF) in ethanol and $1 \mathrm{mM}$ EDTA pH 7.4 and vortexed for $5 \mathrm{~s}$ [27]. The sample was then homogenized using a Polytron for $3 \times 10 \mathrm{~s}$ on ice and thereafter the homogenates were sonicated for $3 \times 5 \mathrm{~s}$. Subsequently, two volumes of muscle homogenate and one volume of SDS-sample buffer (2.3\% SDS, $62.5 \mathrm{mM}$ TRIS HCl pH 6.8, 10\% gylcerol, $5 \% \beta$-mercaptoethanol, $0.05 \%$ bromophenol blue) were boiled for $4 \mathrm{~min}$ followed by centrifugation for $5 \mathrm{~min}$ at 13,000 rpm. Two $12 \%$ polyacrylamide gels containing $0.1 \%$ SDS were run. The first gel was used to calculate protein concentrations by densitometry scanning using Imagemaster (Pharmacia Biotech), after Coomassie staining. On the second gel equal amounts of protein were loaded in each lane based on the protein calculations from the first gel and electrophoresis performed using a Mini-Protean 3 electrophoresis cell. Following electrophoresis, blotting was performed using a Mini Trans-Blot electrophoretic transfer cell and a nitrocellulose membrane $(0.45 \mu \mathrm{m}$, Bio-Rad Laboratories) for $1 \mathrm{~h}$ at $100 \mathrm{~V}$ in a cold $\left(4^{\circ} \mathrm{C}\right)$ buffer containing $25 \mathrm{mM}$ TRIS pH 8.8 , $192 \mathrm{mM}$ glycine, and $20 \%$ methanol. After protein transfer, nitrocellulose membranes were blocked with $5 \%$ nonfat dry milk in PBS containing $0.05 \%$ Tween-20 and thereafter antibody incubation was performed with gentle shaking overnight at room temperature at a dilution of 1:5,000 in the 5\% nonfat dry milk in $0.5 \%$ Tween-20/PBS. A rabbit anti-human UCP3 antibody (code:1331, kindly provided by L.J. Slieker, Eli Lilly) prepared against a 20-amino acid (aa) peptide (human sequence aa 147-166), which recognizes both the long and short UCP3 isoforms and was previously shown not to recognize UCP2, was used [19, 27].

After the primary antibody incubation, the membranes were incubated for $60 \mathrm{~min}$ with a horseradish peroxidase-conjugated swine anti-rabbit Ig (DAKO, Glostrup, Denmark) at a dilution of $1: 10,000$. The membranes were then washed for $1.5 \mathrm{~h}$ in $0.05 \%$ Tween20/PBS and again for $20 \mathrm{~min}$ in PBS. Subsequently, they were treated for 1 min with chemiluminescence substrate (Super 
Signal West Dura Extended Duration Substrate; Pierce, Rockford, Ill., USA). Finally, X-ray film (CL-Xposure Film; Pierce, Rockford, Ill., USA) was exposed to the nitrocellulose membranes for 1 min. The reaction product of each blot was analyzed by densitometry using Imagemaster (Pharmacia Biotech).

Immunofluorescence

Serial sections $(5 \mu \mathrm{m})$ were cut for immunofluorescence determination of UCP3, type I and type IIa muscle fibers. Each section was placed on glass slides and air-dried for $2 \mathrm{~h}$ at room temperature. The sections were then fixed in methanol for $5 \mathrm{~min}$ at room temperature and acetone $\left(-20^{\circ} \mathrm{C}\right)$ for $1 \mathrm{~min}$. Following this the sections were incubated in a solution of $50 \%$ normal goat serum (NGS) and 3\% BSA in PBS for $30 \mathrm{~min}$ at room temperature. The primary UCP3 antibody was diluted 1:400. For the detection of type I and IIa muscle fibers respectively, a monoclonal antibody (A4.951; IgM) raised against adult human slow myosin heavy chain at a dilution of $1: 20$ and a monoclonal antibody $\left(\mathrm{N} 2.261 ; \operatorname{IgG}_{1}\right)$ reactive with adult human fast IIa myosin heavy chain at a dilution of 1:20 were used. Both antibodies were developed by Dr. Blau [28]. The three antibodies were diluted in 10\% NGS and 1\% BSA in PBS. After overnight incubation at $4^{\circ} \mathrm{C}$ the sections were washed $3 \times 5$ min in PBS. The primary antibodies were visualized by the following secondary antibodies: goat anti-rabbit Ig conjugated with fluorescin isothiocyanate [GARIgFITC; Southern Biotechnology Associates (SBA), Birmingham, Ala., USA; goat anti-mouse IgM conjugated with Texas Red (GAMIgMTxRd; SBA) and goat antimouse $\operatorname{IgG}_{1}$ conjugated with Alexa Fluor 350 (GAMIg Alexa Fluor 350; Molecular Probes Europe, Leiden, The Netherlands)] for 30 min at room temperature. Due to difficulty in obtaining suitable morphological muscle cross sections (small cross-sectional area and/or tissue damage) from all 18 subjects muscle samples were analyzed from 5 UTr and $5 \operatorname{Tr}$ subjects with a mean \pm SD of $75 \pm 10$ fibers counted. This subgroup of 10 was representative of the original 18 subjects. There was no significant difference in the [Vitdot] $\mathrm{O}_{2}$ max, MPO or the percentages for the type I, IIa and IIx muscle fibers determined using both the myosin ATPase histochemical and the immunofluorescent staining techniques between the original group and the subgroup ( $P>0.05$ for all analysis) (data not shown). All muscle sections were analyzed at the same time. A total of 390, 271 and 90 type I, IIa and IIx muscle fibers respectively, were counted. Sections were viewed and photographed using a Zeiss Axiophot I microscope mounted with an Axiocam colour CCD camera. The specific fluorescence within each fiber was quantified using the Zeiss KS400 V3.0 program. The rabbit anti-human UCP3 antibody was the same as used for the Western blotting. The specificity of the UCP3 antiserum for immunofluorescence assays was tested on rat $\mathrm{H} 9 \mathrm{C} 2$ myoblasts (lacking endogenous UCP3 expression), which were stably transfected with human UCP3. Additionally, after preincubation of the primary antibody with the peptide (that comprised amino acids 147-166 of human UCP3) no detectable labeling was observed [19].

\section{Statistical analysis}

Two-tailed unpaired $t$-tests were used to compare subject characteristics and total muscle UCP3 expression between the Tr and UTr groups. A two (training status; between factor) $\times$ three (fiber types; within factor) factor ANOVA was used to compare the influence of training status and fiber type on UCP3 protein expression. When a significant interaction between training status and fiber type was observed stratified analysis was used to locate the significant differences. To be specific, one-way repeated measures ANOVA followed by contrasts were used to compare the percentage change in UCP3 between type I, IIa and IIx muscle fibers, for each of the $\mathrm{UTr}$ and $\mathrm{Tr}$ groups. Moreover, the percentage difference in UCP3 between the Tr and UTr group was compared, using the $t$-test, for each of the three fiber types. While the overall alpha level for the
ANOVA was set at 0.05 , the Sharpened Bonferroni method was used to adjust the individual alpha level to significance of $P<0.0167$ when multiple testings were performed in the stratified analysis. The statistical power was $>0.75$ for all analyses, indicating that any nonsignificant results were signs of no differences rather than a consequence of small sample size. All values are reported as mean \pm SD.

\section{Results}

The subject characteristics are provided in Table 1. The Tr group had a significantly higher level of physical fitness as demonstrated by a greater $\dot{V} \mathrm{O}_{2}$ max $(P<0.05)$, MPO $(P<0.01)$, power output per $\mathrm{kg}\left(\mathrm{W} \mathrm{kg}^{-1} ; P<0.05\right)$, mechanical efficiency when cycling at $50 \%$ of $\dot{V} \mathrm{O}_{2}$ max $(P<0.05)$ and CS activity $(P<0.05)$ when compared to the UTr group. Additionally the $\operatorname{Tr}$ group had a greater percentage of type I $(P<0.01)$ and a lower percentage of type IIa $(P<0.01)$ and IIx $(P<0.05)$ muscle fibers as determined by the myosin ATPase histochemical technique when compared to the UTr group.

Figure 1A shows a representative Western blot of the UCP3 protein from an UTr and a Tr subject. The UCP3 protein level measured in whole muscle homogenate was $46 \%$ lower $(P<0.05)$ in the $\operatorname{Tr}$ than in the UTr group (Fig. 1B). A negative correlation between $\dot{V} \mathrm{O}_{2}$ max and UCP3 protein content was observed $(r=-0.63 ; P<0.05$; Fig. 1C).

The triple-immunofluorescent image in Fig. 2 is multiple exposures of the same cross-sectional area demonstrating that the UCP3 protein content is expressed in a hierarchical manner with more in type IIx, less in type IIa and the least in type I muscle fibers. ANOVA demonstrated a significant interaction between training status and UCP3 content in the different muscle fibers $(P<0.001)$.

As shown in Fig. 3 the UCP3 protein expression in both the UTr and Tr groups was significantly more abundant in type IIx fibers than in the type IIa and in the type IIa than in the type I fibers $(P<0.0167)$. Therefore, the hierarchy of UCP3 expression was not modified by training status. As also shown in Fig. 3 UCP3 protein

Table 1 Subject characteristics (CS citrate synthase; $M P O$ maximal power output). Values are mean \pm SD

\begin{tabular}{lcc}
\hline Parameter & Untrained & Trained \\
\hline$n$ & 10 & 8 \\
Age (years) & $22 \pm 3$ & $23 \pm 5$ \\
Mass $(\mathrm{kg})$ & $76 \pm 11$ & $71 \pm 6$ \\
Height $(\mathrm{cm})$ & $183 \pm 10$ & $176 \pm 5$ \\
$\dot{V} \mathrm{O}_{2}$ max $\left(\mathrm{ml} \mathrm{kg}^{-1} \mathrm{~min}^{-1}\right)$ & $51.8 \pm 4.4$ & $67.0 \pm 5.2^{*}$ \\
$\mathrm{MPO}(\mathrm{W})$ & $317 \pm 55$ & $377 \pm 33^{* *}$ \\
$\mathrm{Mechanical} \mathrm{efficiency}(\%)$ & $17 \pm 2$ & $21 \pm 3^{*}$ \\
$\mathrm{~W} \mathrm{~kg} \mathrm{~kg}^{-1}$ body weight & $4.2 \pm 0.3$ & $5.3 \pm 0.4^{*}$ \\
$\mathrm{CS}$ activity ( $\left.\mu m o l \mathrm{~min}^{-1} \mathrm{~g}^{-1}\right)$ & $20 \pm 3$ & $38 \pm 8^{*}$ \\
$\%$ of type I muscle fibers & $52 \pm 11$ & $77 \pm 11^{* *}$ \\
$\%$ of type IIa muscle fibers & $39 \pm 13$ & $19 \pm 12^{* *}$ \\
$\%$ of type IIx muscle fibers & $9 \pm 6$ & $4 \pm 4^{*}$ \\
\hline
\end{tabular}

$* P<0.05 ; * * P<0.01$ compared to untrained subjects 
A
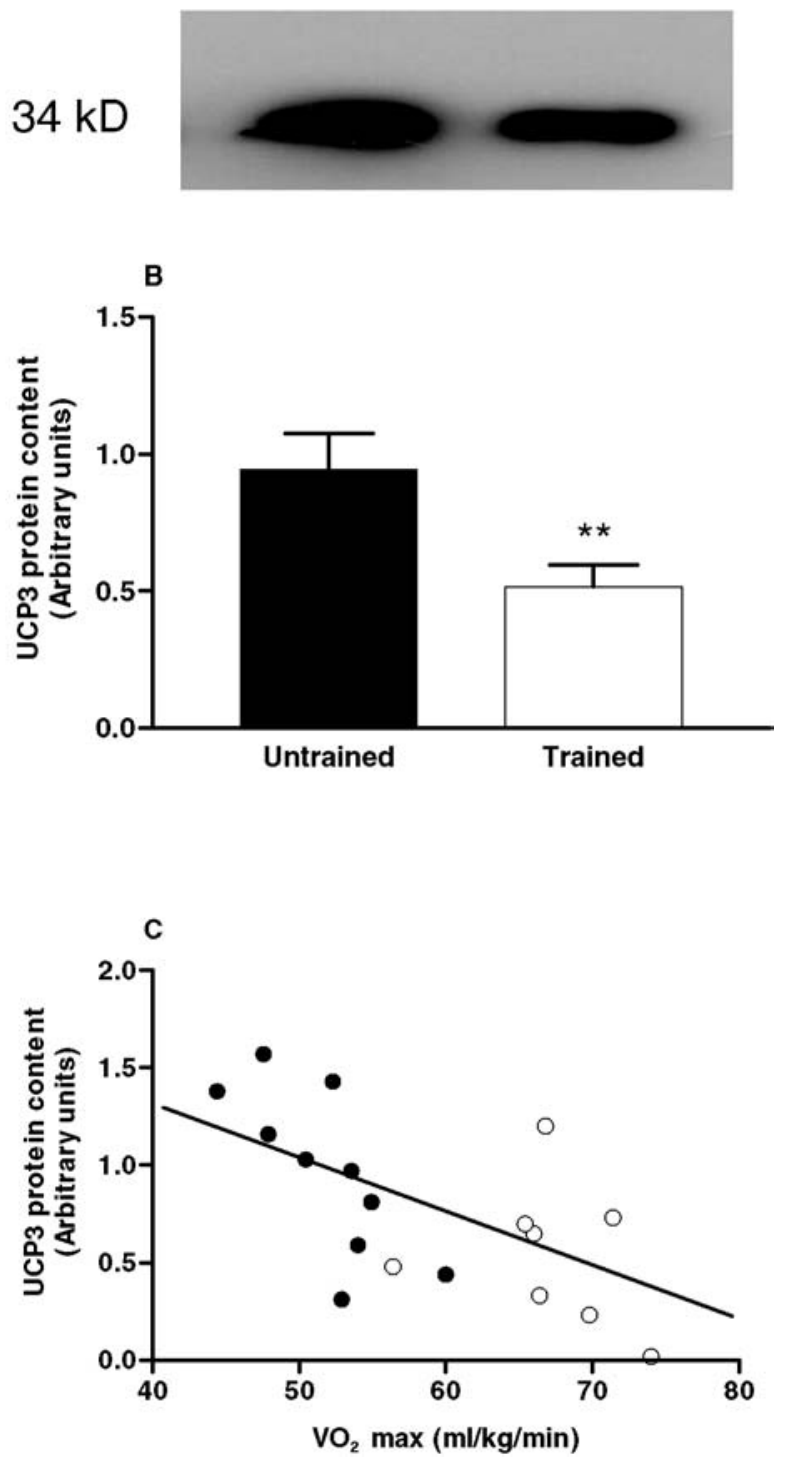

Fig. 1 A Representative Western blot signal of uncoupling protein 3 (UCP3) from an untrained (UTr) and an endurance-trained (Tr) subject. B UCP3 protein content in the $\mathrm{UTr}(n=10)$ and $\operatorname{Tr}(n=8)$ groups $* * P<0.01$. The Western blot was performed as described under materials and methods. $\mathbf{C}$ Negative correlation between $\mathrm{UCP} 3$ and $\dot{V} \mathrm{O}_{2}$ max $\left(\mathrm{ml} \mathrm{kg}{ }^{-1} \mathrm{~min}^{-1} ; r=-0.63 ; P<0.05\right)$; filled circles $\mathrm{UTr}$; open circles Tr. Values are mean \pm SEM

content was lower in all fiber types of the $\operatorname{Tr}$ when compared to the UTr. We thought it interesting to see if training status had a selective effect on UCP3 expression between the fiber types. We observed that the UCP3 protein expression was 33\%, 38\%, and $23 \%$ lower respectively, in the type I, IIa and IIx muscle fibers of the Tr when compared to the UTr subjects $(P<0.001)$. The $33 \%$ and $38 \%$ lower UCP3 protein content in the type I and IIa muscle fibers, respectively, of the $\operatorname{Tr}$ when compared to the UTr group were not significantly different from each other after the Sharpened Bonferroni adjustment $(P>0.0167)$. However, these reductions where significantly more than the $23 \%$ lower UCP3 content in the type IIx muscle fibers of the $\operatorname{Tr}$ when compared to the UTr group $(P<0.0167)$. The discrepancy in the lower UCP3 level in the Tr group determined by Western blot $(46 \% ; n=18)$ and immunofluorescence (average 32\%; $n=10$ ) may be explained by the different subjects used in these analyses. When the Western blot results for the ten subjects used in the immunofluorescence analysis are considered, UCP3 content is 38\% lower in the Tr when compared to the UTr group, although the reduction in sample size results in a loss of statistical significance $(P=0.16$; data not shown).

\section{Discussion}

The first aim of the present study was to compare the skeletal muscle UCP3 protein content in a group of healthy untrained subjects (UTr) to that in endurance trained cyclists (Tr). Our results showed a lower UCP3 protein content in the $\mathrm{Tr}$ when compared to the UTr group. This suggests that subjects with a higher level of aerobic fitness not only have a lower level of UCP3 mRNA $[14,15]$ but also a lower UCP3 protein content. This result confirms data reported previously in subjects after 3 months of endurance cycling training [9]. Reductions in the UCP3 mRNA transcript in Tr when compared to UTr subjects is most likely the cause for the lower UCP3 protein content observed in the present study, however post-translation factors cannot be excluded.

We interpret the lower UCP3 content in the Tr group when compared to the UTr group to be an effect of training, however, the difference in UCP3 protein content may be attributed to the difference in fiber composition. UCP3 protein content is greater in type II than in type I fibers with the former fiber type expressed less in the $\mathrm{Tr}$ than in the UTr muscle. It is therefore possible that the lower UCP3 protein content in the Tr group is due to their lower percentage of type II fibers.

We observed for the first time that the UCP3 protein was expressed decrescendo in IIx $>$ II $>$ I muscle fiber types in a group of endurance trained cyclists. The same muscle fiber type hierarchy also existed in the UTr group which supports results previously reported by Hesselink et al. [19]. Type II muscle fibers have a lower oxidative efficiency than type I muscle fibers. The ratio of phosphate produced per oxygen consumed ( $\mathrm{P} / \mathrm{O}$ ratio) has been found to be $18 \%$ lower in type II than in type I muscle fibers $[29,30]$. The higher UCP3 protein content in type II than in type I fibers might, in part, be responsible for this lower $\mathrm{P}: \mathrm{O}$ ratio.

The observation in endurance trained subjects of an increased resting metabolic rate [11] despite a decrease in muscle UCP3 suggests the idea that UCP3, although it uncouples oxidative phosphorylation, might not be thermoregulatory $[2,3]$. Hence other hypothesized functions have been suggested. Recently it has been reported that the increase in muscle mitochondria proton leak, induced 

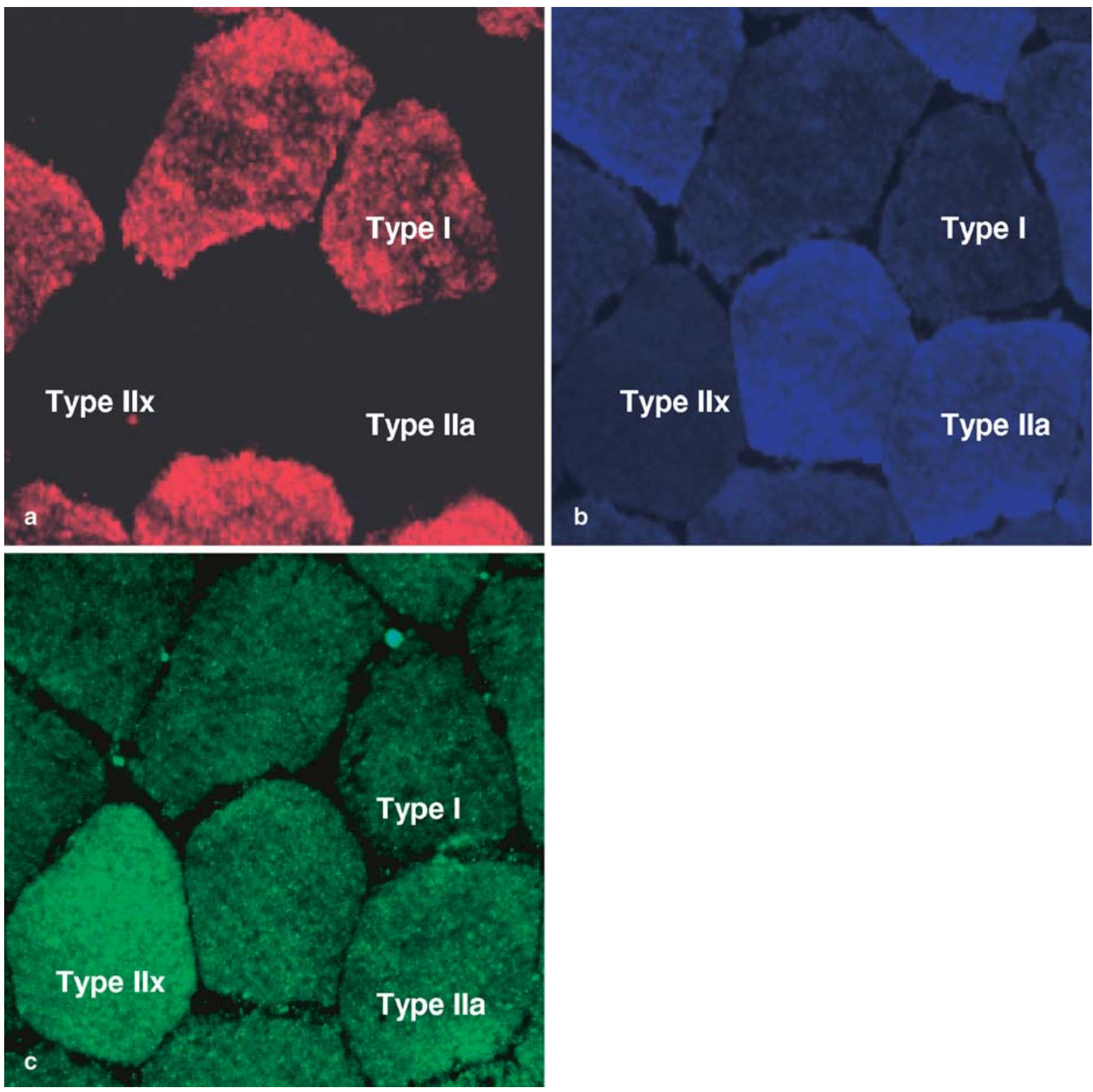

Fig. 2 Triple-immunofluorescent staining of type I muscle fibers stained red; type IIa muscle fibers stained blue; type IIx muscle fibers were unstained; UCP3 protein stained green. The three

by exogenous superoxide production in the presence of free fatty acids, was due to an increase in UCP3 activity [31]. As an extrapolation of these observations a hypothesis was put forward that the biological role of UCP3, in vivo, could be to decrease reactive oxygen species (ROS) production and protect against their deleterious effects.

Muscle contraction has been found to be associated with an increased production of ROS [32,33] while an acute bout of exercise performed in the fasted state has been observed to increase UCP3 mRNA in skeletal muscle $[34,35]$. Endurance training has been shown to reduce exercise-induced ROS production in erythrocytes immediately after a bout of exhausting exercise [36] but not in skeletal muscle when measured $24 \mathrm{~h}$ after exercise

images are of the same area of the same section and demonstrate that UCP3 is expressed the most in type IIx and the least in type I muscle fibers

[37]. These differences may be due to the time of sampling. High-intensity training has been found to increase skeletal muscle anti-oxidant defense [37, 38]. The latter was greater in subjects with a higher as compared to a lower level of aerobic fitness [39]. Therefore training would provide a greater protection against ROS production during exercise. UCP3 mRNA is reduced in subjects with a higher as compared to a lower level of aerobic fitness and is negatively correlated with $\dot{V} \mathrm{O}_{2} \max [14,15]$ and we report in the present study that the UCP3 protein also follows these trends. Therefore a positive relationship might exist at rest and during exercise in UTr and Tr subjects between ROS and UCP3 levels. This suggests that ROS might positively 


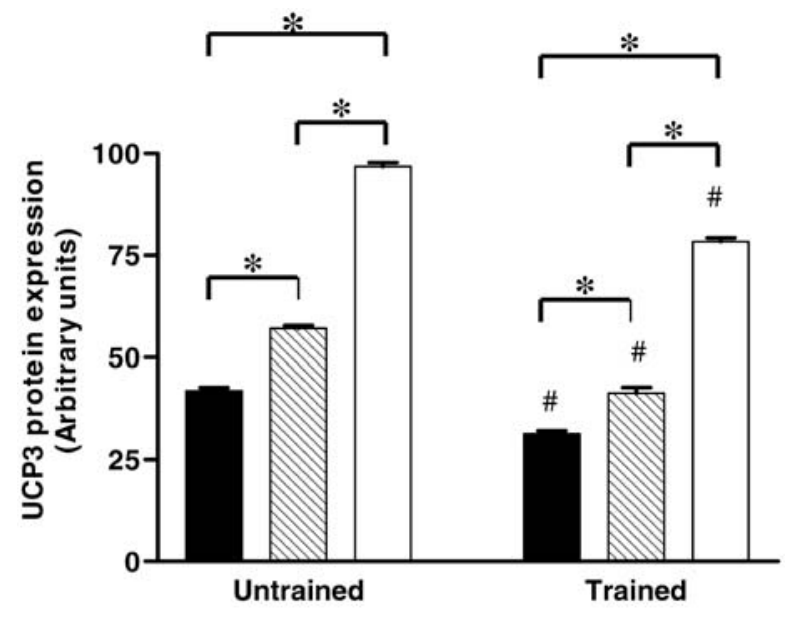

I Ila IIx I Ila IIx

Fig. 3 UCP3 protein content in the different muscle fiber types of the $\mathrm{UTr}(n=5)$ and $\operatorname{Tr}(n=5)$ subjects. Black columns: type I muscle fibers; hatched columns: type IIa muscle fibers; empty columns: type IIx fibers. *Significantly different from each other, $P<0.0167$; **lower expression than in the same fiber of the UTr group, $P<0.001$. Values are mean \pm SEM

regulate not only UCP3 activity [31] but also UCP3 protein level in the mitochondria. Clearly further investigations are required to test this hypothesis.

UCPs have been postulated to uncouple oxidative phosphorylation with a resulting decrease in the efficiency of aerobic ATP production. The consequence of the increase in UCP3 levels during acute exercise would be a decreased mechanical efficiency. The decrease in UCP3 level observed after training on the other hand, might contribute to the training induced improvement in whole body mechanical efficiency during exercise [12]. Indeed this is supported in the present study by a higher mechanical efficiency observed in the Tr when compared to the UT group.

A new finding from the present study is the observation of a similar reduction of UCP3 content in the type I and IIa fibers (33\% and 38\%, respectively) in the $\operatorname{Tr}$ when compared to the UTr group. Antioxidative enzymes have been reported to be predominantly activated in highly oxidative muscle by endurance training in rodents $[40$, 41]. Our observation of a similar reduction in UCP3 in the type I and IIa fibers might mean that endurance training decreases ROS production similarly in these two types of fibers. One possible explanation for the significantly lower decrease in UCP3 in the IIx muscle fibers $(28 \%)$ between the $\operatorname{Tr}$ and UTr subjects might be a reduced recruitment of these fibers during endurance training. Endurance training often occurs at an intensity which preferentially recruits type I muscle fibers [42]. In contrast, sprint training which recruits type II muscle fibers and has been found to increase their antioxidant capacity [43]. Sprint training might also reduce UCP3 content more in these fibers than in type I fibers.
Another proposed function for UCP3 may be to protect the mitochondrial matrix from the toxic effect of accumulating nonesterified fatty acids (NEFAs) in situations where fatty acid delivery exceeds oxidation [9]. This hypothesis is in line with the function of UCP3 as a protector against ROS production as high intracellular levels of fatty acids increase ROS production [44]. The lower UCP3 protein expression in all muscle fiber types of the $\operatorname{Tr}$ group may arise from a reduction in the need to protect mitochondria against high levels of accumulating NEFAs due to an improved fat oxidation capacity [45, 46].

\section{Conclusion}

We observed that the UCP3 protein content was lower in all fiber types of $\operatorname{Tr}$ when compared to UTr subjects. Training status did not effect the hierarchical expression of UCP3 in the different muscle fiber types, however, it affected UCP3 content more in the type I and IIa than in the type IIx muscle fibers. The exact reason for the lower UCP3 content in the Tr when compared to the UTr subjects as well as the differential skeletal muscle fiber type expression of UCP3 remains unknown. We speculate that this decrease may be in relation to the relative improvement in the antioxidant defense systems of the skeletal muscle fibers and that it might, as a consequence, participate in the training induced improvement in mechanical efficiency.

Acknowledgements The monoclonal antibodies directed against adult human and myosin heavy chain isoforms (referred to as A4.951 and N2.261, respectively) used in the present study were developed by Dr. Blau and were obtained from the Development Studies Hybridoma Bank, developed under the auspices of the NICHD and maintained by the University of Iowa, Department of Biological Sciences, Iowa City, IA 52242, USA. Dr. Russell was supported by grants from the Helen M Schutt Trust, Office Féderal du Sport Macolin, Fonds Eugène Rapin, the Fondation du Centenaire de la Société Suisse d'Assurances générales sur la vie humaine pour la santé publique et les recherches médicales and the Sir Jules Thorn Charitable Overseas Trust. This work was also supported by the Swiss National Science Foundation grant no. 31-54306.98. Dr. Schrauwen was supported by a grant from the Netherlands Organisation for Scientific Research (NWO). We thank Eli Lilly and Company for providing us with the UCP3 antibody.

\section{References}

1. Boss O, Samec S, Paoloni G, Rossier C, Dulloo A, Seydoux J, Muzzin P, Giacobino J (1997) Uncoupling protein-3: a new member of the mitiochondrial carrier family with tissuespecific expression. FEBS Lett 408:39-42

2. Boss O, Muzzin P, Giacobino JP (1998) The uncoupling proteins, a review. Eur J Endocrinol 139:1-9

3. Muzzin P, Boss O, Giacobino JP (1999) Uncoupling protein 3: its possible biological role and mode of regulation in rodents and humans. J Bioenerg Biomembr 31:467-473

4. Boss O, Hagen T, Lowell BB (2000) Uncoupling proteins 2 and 3: potential regulators of mitochondrial energy metabolism. Diabetes 49:143-156

5. Schrauwen P, Walder K, Ravussin E (1999) Human uncoupling proteins and obesity. Obes Res 7:97-105 
6. Himms-Hagen J, Harper ME (2001) Physiological role of UCP3 may be export of fatty acids from mitochondria when fatty acid oxidation predominates: an hypothesis. Exp Biol Med 226:78-84

7. Krook A, Digby J, O'Rahilly S, Zierath JR, WallbergHenriksson $\mathrm{H}$ (1998) Uncoupling protein 3 is reduced in skeletal muscle of NIDDM patients. Diabetes 47:1528-1531

8. Vidal-Puig AJ, Grujic D, Zhang CY, Hagen T, Boss O, Ido Y, Szczepanik A, Wade J, Mootha V, Cortright R, Muoio DM, Lowell BB (2000) Energy metabolism in uncoupling protein 3 gene knockout mice. J Biol Chem 275:16258-16266

9. Schrauwen P, Saris WHM, Hesselink MKC (2001) An alternative function for human uncoupling protein-3: protection of mitochondria against accumulation of non-esterified fatty acids inside the mitochondrial matrix. FASEB J 15:2497-2502

10. Schrauwen P, Hesselink MK, Blaak EE, Borghouts LB, Schaart G, Saris WH, Keizer HA (2001) Uncoupling protein 3 content is decreased in skeletal muscle of patients with type 2 diabetes. Diabetes 50:2870-2873

11. Tremblay A, Fontaine E, Poehlman ET, Mitchell D, Perron L, Bouchard C (1986) The effect of exercise-training on resting metabolic rate in lean and moderately obese individuals. Int J Obes 10:511-517

12. Gissane C, Corrigan DL, White JA (1991) Gross efficiency responses to exercise conditioning in adult males of various ages. J Sports Sci 9:383-391

13. Boss O, Samec S, Desplanches D, Mayett M, Seydoux J, Muzzin P, Giacobino J (1998) Effect of endurance training on mRNA expression of uncoupling proteins $1,2,3$ in the rat. FASEB J 12:335-339

14. Schrauwen P, Troost FJ, Xia J, Ravussin E, Saris WH (1999) Skeletal muscle UCP2 and UCP3 expression in trained and untrained male subjects. Int J Obes Relat Metab Disord 23:966972

15. Russell AP, Wadley G, Snow RJ, Giacobino JP, Muzzin P, Garnham A, Cameron-Smith D (2002) Influence of skeletal muscle fiber type, citrate synthase activity and UCP3 mRNA on the slow component of $\mathrm{VO}_{2}$ kinetics. Int $\mathrm{J}$ Obes Relat Metab Disord 26:157-164

16. Cadenas S, Buckingham JA, Samec S, Seydoux J, Din N, Dulloo AG, Brand MD (1999) UCP2 and UCP3 rise in starved rat skeletal muscle but mitochondrial proton conductance is unchanged. FEBS Lett 462:257-260

17. Sivitz WI, Fink BD, Donohoue PA (1999) Fasting and leptin modulate adipose and muscle uncoupling protein: divergent effects between messenger ribonucleic acid and protein expression. Endocrinology 140:1511-1519

18. Lange P de, Lanni A, Beneduce L, Moreno M, Lombardi A, Silvestri E, Goglia F (2001) Uncoupling protein-3 is a molecular determinant for the regulation of resting metabolic rate by thyroid hormone. Endocrinology 142:3414-3420

19. Hesselink MK, Keizer HA, Borghouts LB, Schaart G, Kornips CF, Slieker LJ, Sloop KW, Saris WH, Schrauwen P (2001) Protein expression of UCP3 differs between human type 1, type $2 \mathrm{a}$, and type $2 \mathrm{~b}$ fibers. FASEB J 15:1071-1073

20. Apple FS, Tesch PA (1989) CK and LD isozymes in human single muscle fibers in trained athletes. J Appl Physiol 66:2717-2720

21. Febbraio M, Snow R, Hargreaves M, Stathis C, Matrin I, Carey M (1994) Muscle metabolism during exercise and heat stresses in trained men: effect of acclimation. J Appl Physiol 76:589-597

22. Srere P (1969) Citrate synthase. Academic Press, New York

23. Tonkonogi M, Harris B, Sahlin K (1997) Increased activity of citrate synthase in human skeletal muscle after a single bout of prolonged exercise. Acta Physiol Scand 161:435-436

24. Hoppeler H (1986) Exercise-induced ultrastructural changes in skeletal muscle. Int J Sports Med 7:187-204

25. Spina RJ, Chi MM, Hopkins MG, Nemeth PM, Lowry OH, Holloszy JO (1996) Mitochondrial enzymes increase in muscle in response to 7-10 days of cycle exercise. J Appl Physiol $80: 2250-2254$
26. Brook MH, Kaiser KK (1970) Muscle fiber types: how many and what kind? Arch Neurol 23:369-379

27. Schrauwen P, Schaart G, Saris WH, Slieker LJ, Glatz JF, Vidal H, Blaak EE (2000) The effect of weight reduction on skeletal muscle UCP2 and UCP3 mRNA expression and UCP3 protein content in Type II diabetic subjects. Diabetologia 43:1408-1416

28. Cho W, Webster S, Blau H (1993) Evidence for extrinsic regulation of slow myosin heavy chain expression during muscle fiber development. J Cell Biol 121:795-810

29. Crow MT, Kushmerick MJ (1982) Chemical energetics of slow- and fast-twitch muscles of the mouse. J Gen Physiol 79:147-166

30. Kushmerick MJ, Meyer RA, Brown TR (1992) Regulation of oxygen consumption in fast- and slow-twitch muscle. Am J Physiol 263:C598-C606

31. Echtay KS, Roussel D, St-Pierre J, Jekabsons MB, Cadenas S, Stuart JA, Harper JA, Roebuck SJ, Morrison A, Pickering S, Clapham JC, Brand MD (2002) Superoxide activates mitochondrial uncoupling proteins. Nature 415:96-99

32. Davies KJ, Quintanilha AT, Brooks GA, Packer L (1982) Free radicals and tissue damage produced by exercise. Biochem Biophys Res Commun 107:1198-1205

33. Jackson MJ, Edwards RH, Symons MC (1985) Electron spin resonance studies of intact mammalian skeletal muscle. Biochim Biophys Acta 847:185-190

34. Pilegaard H, Ordway GA, Saltin B, Neufer PD (2000) Transcriptional regulation of gene expression in human skeletal muscle during recovery from exercise. Am J Physiol 279:E806E814

35. Schrauwen P, Hesselink MK, Vaartjes I, Kornip E, Sari WH, Giacobino J-P, Russell A (2002) The effect of acute exercise on uncoupling protein 3 is a fat metabolism mediated effect. Am J Physiol 282:E11-E17

36. Miyazaki H, Oh-ishi S, Ookawara T, Kizaki T, Toshinai K, Ha S, Haga S, Ji LL, Ohno H (2001) Strenuous endurance training in humans reduces oxidative stress following exhausting exercise. Eur J Appl Physiol 84:1-6

37. Ortenblad N, Madsen K, Djurhuus MS (1997) Antioxidant status and lipid peroxidation after short-term maximal exercise in trained and untrained humans. Am J Physiol 272:R1258R263

38. Hellsten Y, Apple FS, Sjodin B (1996) Effect of sprint cycle training on activities of antioxidant enzymes in human skeletal muscle. J Appl Physiol 81:1484-1487

39. Jenkins RR, Friedland R, Howald H (1984) The relationship of oxygen uptake to superoxide dismutase and catalase activity in human skeletal muscle. Int J Sports Med 5:11-14

40. Ji LL, Stratman FW, Lardy HA (1988) Antioxidant enzyme systems in rat liver and skeletal muscle. Influences of selenium deficiency, chronic training, and acute exercise. Arch Biochem Biophys 263:150-160

41. Powers SK, Criswell D, Lawler J, Martin D, Lieu FK, Ji LL, Herb RA (1993) Rigorous exercise training increases superoxide dismutase activity in ventricular myocardium. Am J Physiol 265:H2094-H2098

42. Sale DG (1987) Influence of exercise and training on motor unit activation. Exerc Sport Sci Rev 15:95-151

43. Atalay M, Seene T, Hanninen O, Sen CK (1996) Skeletal muscle and heart antioxidant defences in response to sprint training. Acta Physiol Scand 158:129-134

44. Maziere C, Conte MA, Degonville J, Ali D, Maziere JC (1999) Cellular enrichment with polyunsaturated fatty acids induces an oxidative stress and activates the transcription factors AP1 and NFkappaB. Biochem Biophys Res Commun 265:116-122

45. Hurley BF, Nemeth PM, Martin WH, 3rd, Hagberg JM, Dalsky GP, Holloszy JO (1986) Muscle triglyceride utilization during exercise: effect of training. J Appl Physiol 60:562-567

46. Klein S, Coyle EF, Wolfe RR (1994) Fat metabolism during low-intensity exercise in endurance-trained and untrained men. Am J Physiol 267:E934-E940 